\title{
UNIVERSITYOF
}

FORWARD

THINKING

WESTMINSTER用

WestminsterResearch

http://www.westminster.ac.uk/westminsterresearch

Digital BRICS: Building a NWICO 2.0?

Thussu, D.K.

This is an Accepted Manuscript of a book chapter published by Routledge in Mapping BRICS Media on 17 March 2015, available online:

http://www.routledge.com/9781138026254

The WestminsterResearch online digital archive at the University of Westminster aims to make the research output of the University available to a wider audience. Copyright and Moral Rights remain with the authors and/or copyright owners.

Whilst further distribution of specific materials from within this archive is forbidden, you may freely distribute the URL of WestminsterResearch: ((http://westminsterresearch.wmin.ac.uk/).

In case of abuse or copyright appearing without permission e-mail repository@westminster.ac.uk 


\section{Digital BRICS: Building a NWICO 2.0?}

\section{Daya Kishan Thussu}

The international presence of BRICS media is likely to expand exponentially with the growing convergence of mobile communications technologies and content via an altered and multi-lingual internet. The predominance of English on the internet might also be undermined, creating tendencies towards a fragmented internet. China, which hosts the world's largest blogging population and its version of Facebook QZone - has more than 600 million users by 2014; while Weibo (the Chinese version of Twitter), has an equally large following and is increasingly influencing mainstream journalism within the Sino media-sphere. Internet users in India are expected to reach 600 million by 2020 , driven by wireless connections. Russia already has the highest internet penetration among the BRICS nations. In Brazil too, the internet is expanding at a rapid pace, while the growth of mobile internet in South Africa is likely to increase as $3 \mathrm{G}$ becomes more affordable. What implications will such digital connectivity have for global news flows, information and communication agendas, both in the BRICS countries and beyond? This chapter aims to evaluate how current and potential developments in digital, internet-based media in the BRICS countries might impact on global communication. It maps these developments and analyses them within the context of questions about internet governance and suggests that, given the scope and scale of change in BRICS countries, a New World Information and Communication Order may be evolving - a NWICO 2.0.

\section{BRICS in the context of NWICO}

Despite its many internal differences and complex external affiliations, the BRICS group shares their non-Euro-Atlantic origins as well as their consistent calls to redress power imbalances in existing international institutions and structures. In this respect, these nations represent a much older and often forgotten demand for a fairer and more just international order, with its roots in the Non-Aligned Movement, of which India was a founding member and a leading exponent. The demand for a New World Information and Communication Order (NWICO), which dominated international communication debates during the 1970s and 1980s, most significantly within UNESCO, in its essence argued that the international information system, because of its structural logic, reinforced and perpetuated inequality, with serious 
implications for the countries of the global South, which were heavily dependent on the West for both information software and hardware (Nordenstreng and Padovani, 2005; Pickard, 2007; Nordenstreng, 2012; Thussu, 2015). It was argued by NWICO supporters that, owing to economic, political, social and technological imbalances, there was 'a one-way flow' of information from the 'centre' to the 'periphery,' which created a wide gap between the 'haves' and the 'have nots.' This 'vertical' flow (as opposed to a more desirable, horizontal flow of global information) was dominated by Western-based transnational corporations, which treated information as a 'commodity' and subjected it to the rules of the market. It was argued that there existed a 'flagrant quantitative imbalance between North and South created by the volume of news and information emanating from the developed world and intended for the developing countries and the volume of the flow in the opposite direction'. Therefore, 'by transmitting to developing countries only news processed by them, that is, news which they have filtered, cut, and distorted, the transnational media impose their own way of seeing the world upon the developing countries' (Masmoudi, 1979: 172-173).

Western governments, led by the US, saw in the call for a NWICO a 'Sovietinspired', Third-World design to control the media through state regulation. As a concept it was seen as one fundamentally in conflict with liberal Western values and the principle of the 'free flow of information'. Their response was also affected by Cold War assumptions that made the West place the issues regarding global newsflow in the context of East-West rivalry. The opponents of NWICO argued that it was a pretext for Third-World dictators to stifle media freedom and to impose censorship. The Western governments and their commercial media viewed the NWICO demands as 'entailing too interventionist a role for the state and also as likely to result in the exclusion of foreign journalists, with consequent restriction of information flows' (Wells, 1987: 27).

As a result of the protracted debates, the International Commission for the Study of Communication Problems was set up in 1977. The MacBride Commission, as it was popularly known, submitted its final report to UNESCO in 1980, a document which, for the first time, elevated information- and communication-related issues onto the global agenda. Out of the 16 members of this Commission, only two represented the BRICS nations - India and Russia (then Soviet Union). The other three BRICS countries had virtually no contribution to the NWICO debate: China was 
conspicuously absent from the deliberations; Brazil was ruled during that period by a pro-US military dictatorship, while South Africa was under an apartheid regime with very limited international diplomatic exposure.

Much has changed in the world since those ideologically-charged days of East-West/North-South dichotomies. In the post-Cold War, post-Communist, neoliberal globalized world, new geo-political and economic constellations are emerging and old ones being reconfigured. The BRICS nations represent a striking example of this changed globe, also notable in the field of media and communication. As Castells has suggested 'communicative action' remains the key to power (Castells, 2009: 50) and as their communicative power increases, what will be the impact of the BRICS nations on the global information and communication system?

\section{Digital growth and BRICS}

The most significant change in global media is the exceptional growth in digital communication. According to PricewaterhouseCoopers' report, Global Entertainment and Media Outlook 2014-2018, global mobile internet penetration will reach 55 per cent by 2018, which will enable digital advertising to increase its share of total advertising revenue, to an estimated 33 per cent, up from 14 per cent in 2009. Industry reports suggest that the BRICS nations are likely to see a surge in the TV subscription market, as well as in the advertising sector, since they 'possess both high growth rates and major scale' (PwC, 2014). According to PwC, China, with total internet advertising revenue of more than $\$ 30$ billion in 2018, will be the largest of the 'higher-growth, larger-scale' markets. In newspapers too, China, India and Brazil are likely to witness impressive expansion. The 2013 World Press Trends survey by the World Association of Newspapers and News Publishers reports that 800 million now access news online, an increasingly large number of them among BRICS nations (WAN-IFRA, 2014). Though the US will be the world's biggest entertainment and media market in 2018, in terms of digital revenues and internet advertising, China will have 'dramatically narrowed the gap' (PwC, 2014). China will also become the world's largest film market by 2020, says a UNESCO report, noting that Brazil, Russia, India and China are increasing the 'share of the world film market (both production and admissions), with China being 'the main star of this story: 
based on conservative estimates, by early 2020 the Asiatic giant will surpass US as the main film market in the world' (UNESCO, 2013: 34).

The growth is also remarkable in the other Asian giant, India, where it took a decade for the number of internet users to grow from 10 million to 100 million, but just three years to double that number to 200 million (FICCI/KPMG Report, 2014: 98). India's Minister of Communications and IT, Ravi Shankar Prasad, told Parliament in August 2014 that the number of internet users in the country had reached nearly 252 million by March 2014. An estimated two million new users are added every month to social media networks in India, which is expected to have the largest Facebook population by 2016, surpassing the US (FICCI/KPMG Report, 2014: 119). The projected growth in India's internet users is likely to be 'the highest incremental growth in the world', says a McKinsey report noting:

India has significant advantages that make it fertile ground for an internetenabled transformation: a youthful demographic profile that will produce a large future wave of early adopters of technology; a large pool of workers with technical education; and a strong culture of entrepreneurship and the ability to adapt business models for a resource $\square$ constrained environment.

(Gnanasambandam et al, 2012: 11)

With the expansion of $3 G$ and gradual introduction of $4 G$ services, paralleled with the affordability of smartphones as telecom companies achieve economies of scale, more and more internet users are likely to be mobile $\square$ only subscribers using internet-enabled devices (ibid). In 2013, India had 42 million 3G connections, expected to grow to about 369 million by 2018 (FICCI/KPMG Report, 2014: 102). Industry estimates suggest that digital advertising spending will reach about $\$ 2$ billion by 2018 , compared to $\$ 26$ billion for China and nearly $\$ 80$ billion for the US. However, the biggest potential change is in the countryside - in 2013, for the first time in India's history, there were more rural than urban readers of newspapers (UNESCO, 2014).

As India's ambitious National Optical Fibre Network is completed, with a plan to provide broadband connectivity to 250,000 gram panchayats (village councils) serving 600,000 villages and over 1.15 billion people, it will considerably improve access to citizen services and the quality of information collected at the grassroots level. As a result, the rural communication scene is likely to be transformed 
(FICCI/KPMG Report, 2014: 98). Another feature of this transformation is the increasing realisation that, while English remains a link language within India and a vehicle for global communication, the real growth is in India's indigenous languages. Already Google has launched a Hindi handwriting tool for search, and Mozilla Firefox a Tamil version of its browser, while Samsung announced the launch of regional language user interface and applications for its Indian customers (FICCI/KPMG Report, 2014: 106). As the McKinsey report observes: 'The next wave of internet adoption in India will be dominated by local language speakers' (Gnanasambandam et al, 2012: 17).

Such connectivity is encouraging businesses to invest in communication infrastructure: in 2014, one of India's biggest corporations, Reliance Industries, acquired Network 18 - the country's premier news and entertainment channel - and is introducing $4 \mathrm{G}$ broadband network in a phased manner under the brand of 'Reliance Jio' Infocomm ('live' in Hindi). The suggestion is that, as the internet infrastructure is strengthened and millions of Indians start using digital platforms and services, corporatized news from Network 18 - which owns many channels - will provide the content for the telecom company. India's e-retailing market, too, is predicted to reach $\$ 20$ billion by 2020. In 2014, India's response to Amazon Flipkart.com, the country's largest e-commerce company - attracted $\$ 1$ billion in funding from investors - unprecedented in Indian corporate history (Thoppil, 2014).

As the McKinsey report notes: 'If India achieves its potential for growth in the number of internet users and internet technology-related consumption and investment, the internet's contribution to GDP would be nearly $\$ 100$ billion in 2015' (Gnanasambandam et al, 2012: 2). However, in comparison to its BRICS partners, India lags behind considerably: in contrast to Brazil and South Africa it has only approximately six per cent of the number of secure internet servers per capita. Also impeding its growth is high cost of access and usage, one of the highest costs of broadband access: more than four times that of China and Brazil (ibid).

In China, where nearly half the population was online in 2014, the scale of the digital revolution is even greater and the impact of this is being experienced across the globe. The 2014 announcement of the public offering of Alibaba, China's largest e-commerce company on the New York Stock Exchange - valued at $\$ 200$ billion generated much interest in the global business press, an indication of the changing 
contours of global digital capitalism. WeChat, an app owned by Chinese firm Tencent, which allows users to create personal profiles or subscription profiles, in 2014 had 400 million users. Apart from providing consumer brands to reach a tailormade audience, such digital connectivity has also helped WeChat to emerge as a platform for critical journalists in China to work around state censorship. China Daily, the English-language mouthpiece of the government, is available as Real Time China on WeChat. Like many Chinese-language publishers, they use WeChat to share articles and pictures about topics trending on the web. In India, Brazil and South Africa, journalists are increasingly using social media to supplement mainstream media and, in some cases, also to demand greater transparency from governments.

Among the BRICS nations, Brazil has the highest internet penetration after Russia. Brazilians are 'among the world's top users of blogs and social networks (in 2013, there were 80 million Facebook users in Brazil) and use of online media is growing fast, attracting foreign outlets like BuzzFeed, the Spanish newspaper El País and the Huffington Post, which launched their Portuguese versions' (Newman and Levy, 2014: 36).

In Russia, the internet industry is characteristically indigenous, as its social networking sites (VKontakte), blogging platforms (LiveJournal) and search engines (Yandex), are largely in Russian. Known popularly as the 'Runet', the Russianlanguage internet has demonstrated exceptional growth: in the period 2003-2013, the main Russian top level domain '.ru' grew from 200,000 to about 4.5 million. Internet usage in South Africa has more than doubled in the last four years. According to the State of the Newsroom SA 2013 study, one third of the country's adult population were on the internet and that figure is expected to double by 2016. The Government is planning for broadband access to every citizen by 2020 (quoted in FICCI-KPMG Report, 2014). One reason for this expansion is the growing use of mobile internet across the world. According to 2014 Ericsson Mobility Report, there were 1.9 billion smartphone subscriptions in 2013 and a ten-fold growth in mobile data traffic between 2013 and 2019 is predicted, mostly in the developing world. Mobile broadband subscriptions had reached 2.3 billion in 2014 - by 2019 these were expected to account for more than 80 per cent of all mobile subscriptions (Ericsson Mobility Report, 2014: 6). 


\section{Surveillance and security: a Cyber Cold War?}

This global connectivity is raising concerns about security in the digital domain. Countries, corporations and individuals are increasingly anxious to protect their cyber assets as 'internet of things' begins to take firmer shape (US Government, 2014). According to the research firm Gartner, organizations around the globe spent $\$ 67$ billion on information security in 2013. Despite the rhetoric of a cyber war or a terrorist attack on electrical grids and communications networks - a 'cyber 9/11' - it has been argued that the real threat is espionage, sabotage and subversion (Rid, 2013). However, it is not state-less terrorist outfits but national governments which have been blamed for digital sabotage. One example was 'the destruction in 2010 of centrifuges at a nuclear facility in Iran by a computer programme known as Stuxnet', the handiwork of US and Israeli 'software experts' (Economist, 2014).

Some BRICS members have contended that the US wields great influence on internet infrastructure, thus undermining the security and sovereignty of other nations (Ebert and Maurer, 2013). Given that the internet was developed in the US - within its military-industrial-complex, evolving from a network infrastructure created by the Department of Defense - it has a strong American stamp on it. This goes back to the 1990s when the internet was privatized and globalized and the creation of ICANN (1998) (the Internet Corporation for Assigned Names and Numbers), the US-based non-profit organization which coordinates a vital aspect of online communication the Internet Protocol addresses and domain names system (DNS), so that users can send and receive information from any web-connected device. It was set up under contract to the US Department of Commerce, with its National Telecommunications and Information Administration assuming a lead role within the organization (Kruger, 2014). These issues have become prominent since the internet is increasingly affecting all aspects of life for people across the globe. As ICANN's draft Five Year Strategic Plan 2016-2020, released in April 2014, notes: 'By the end of 2020, it is estimated there will be as many as one trillion 'things' connected to the internet, using the DNS as a platform for a range of services for the world's users. This will expand the very nature of the internet from an on-demand human service to an always on, near continuous use service for sensors and machines' (Cerf et al, 2014). 
The age of ubiquitous digital services and 'cloud computing', with services like iCloud, Google Drive and Dropbox, will transform data storage and access across the globe with implications for data-mining and trading (Fuchs et al, 2011; Mosco, 2014). Corporations are particularly concerned about the security of intellectual property rights in the digital realm. A study by the US-based Centre for Strategic and International Studies estimates that globally the annual cost of digital crime and intellectual-property theft was $\$ 445$ billion (Lewis and Baker, 2013). Given that it is mostly US-based and owned corporations - notably Microsoft, Google, Facebook, PayPal, Amazon, Twitter, Yahoo - which effectively control global internet traffic, questions have been raised about data protection and the issues of digital surveillance and spying (Fuchs et al, 2011; Mosco, 2014, among others). A vast majority of internet users - over 90 per cent - deploy tools and platforms developed by these companies, making them vulnerable to consumer surveillance and worse. Google, for example, accounts for nearly 70 per cent share of the global search engine market, while global paid search internet advertising has the largest share of total internet advertising revenue, at $\$ 48.4 \mathrm{bn}$ in 2013 (PwC, 2014).

The 2013 exposés by former National Security Administration (NSA) contractor Edward Snowden about NSA spying revealed 'the US government's vast capacity to intercept communications around the world'. These not only 'appear to have damaged one major element of America's global image: its reputation for protecting individual liberties', as a Pew Survey found (Pew Research Center, 2014: 6), but also contributed to what has been termed as a cyber Cold War among the main protagonists of the original Cold War - US and Russia (the country where Snowden has been granted political asylum). Apart from revealing the extent of global surveillance that the US government was routinely undertaking- ranging from diplomatic negotiations to corporate spying, to issues of individual privacy - the Snowden affair also demonstrated the collusion of major internet corporations in this enterprise.

The BRICS countries - especially Russia - were particularly exercised by this, prompting President Putin to even suggest that the Russian search engine Yandex was controlled by Western intelligence agencies. In Brazil, where NSA had listened to the private phone conversations of President Dilma Rousseff, the image US declined considerably - from 69 per cent in 2013 to 52 per cent in 2014 (Pew 
Research Center, 2014). Brazil also announced the creation of fibre-optic submarine cables which will link up Brazil directly with Western Europe (thus bypassing the US). In addition, it introduced a bill that would mandate the storing of digital data on Brazilians in Brazil, thus contributing to the emergence of a 'national internet.'

\section{Safeguarding cyber sovereignty}

In the internet age of global and globalized communication the governance of the internet becomes a crucial element and the BRICS nations, given the scale and scope of their digital growth, are key players in this global tussle (Ebert and Maurer, 2013). Of the five BRICS nations, there are strikingly different approaches with regard to the governance of the internet, while the members of IBSA - India, Brazil and South Africa - by and large, follow the US-led model championing a 'multistakeholders' approach; Russia and China have argued for a UN-approved and managed governance structure with such intergovernmental organizations as the International Telecommunications Union (ITU) undertaking a primary role in defining and implementing governance, and for a reduced role for ICANN. At the heart of the debate are two competing views - the 'sovereignist' where national governments take the major decisions, and a market-led privatized network - on how the most significant global network should be governed.

The Snowden disclosures of US government surveillance practices, including the monitoring of foreign leaders, have reignited an international debate over internet governance. The US modelled regulation for the new areas of communication, it has been argued applies 'neo-liberal logics as a part of its efforts to recreate the transnational hegemonic communication system' (Bhuiyan, 2014: 38). Governing the internet has been a deeply contested issue. In 2005, the UN-sponsored World Summit on the Information Society (WSIS) defined internet governance as 'the development and application by governments, the private sector and civil society, in their respective roles, of shared principles, norms, rules, decision-making procedures, and programs that shape the evolution and use of the internet' (WSIS, 2005). Under pressure from many member states, the UN's response to USinfluenced ICANN was the establishment in 2006 at the WSIS of the Internet Governance Forum (IGF), an international group of governments and 
nongovernmental entities, to discuss internet-related policies (Nordenstreng and Padovani, 2005; Pickard, 2007).

Since then, the internet has grown exponentially and a range of issues - from cyber security to digital property rights to electronic commerce - have complicated the governance discourse (US Government, 2014). As Mueller has suggested, the internet's 'transnational scope, boundless scale, distributed control, new institutions, and radical changes in collective action capabilities ... are transforming national control and sovereignty over communication and information policy' (Mueller, 2010: 5). He has argued that internet governance can be best conceptualized as 'networked governance,' which provides 'one possible way of bridging the gap between national institutions and global connectivity' (ibid: 6). Networks that 'combine state and non-state actors', Mueller has argued, 'can overcome some of the limitations of the government based on territorial sovereignty' (ibid: 7).

The IGF followed a 'multi-stakeholder model' promoted by ICANN, where governments shared policy debates with private sector and civil society groups (Pickard, 2007; Bhuiyan, 2014). Mueller has called multi-stakeholder governance as a 'pluralization of international institutions' (Mueller, 2010: 8). Some BRICS governments saw this as a cloak for legitimizing a commercialized neo-liberal policy structure developed to protect and promote digital corporations, most of which are based in the US. China's attitude on this issue is clearly stated in its 2010 White Paper:

China believes that UN should be given full scope in international internet administration and supports the establishment of an authoritative and just international internet administration organization under the UN system through democratic procedures on a worldwide scale. All countries have equal rights in participating in the administration of the fundamental international resources of the internet. (Government of China, 2010)

Russia too prefers a model that is state-centric and based on the inviolability of state sovereignty, favouring a greater role for the UN. Both countries have serious concerns about the control of internet by the US and its capacity to compromise security both in virtual and real world. 
There is a domestic dimension of this attitude as well: both countries exercise extensive and deeply embedded control and censorship regimes: the so-called 'Great Firewall of China' - an effective information filtering mechanism - is the most cited example of this (Yang, 2009; Ng, 2013). In Russia too, governmental control over internet intermediaries and service providers is strong. However, unlike Russia, Chinese global presence is growing and digital capitalism is increasingly important to its version of capitalism 'with Chinese characteristics', which is very open to foreign investment and international trade but still closed to political pluralism.

At the UN-sponsored World Conference on International Telecommunication held in Dubai in December 2012, Russia and China, as two key countries, introduced a proposal stating: 'Member States shall have equal rights to manage the internet, including in regard to the allotment, assignment and reclamation of internet numbering, naming, addressing and identification resources to support for the operation and development of basic internet infrastructure' (ITU, 2012a).

Unsurprisingly, it was rejected by the US, asserting that 'the United States continues to believe that internet policy must be multi-stakeholder-driven' and that it 'should not be determined by member states, but by citizens, communities, and broader society' (US Government, 2012). The proposal was subsequently withdrawn and the ITU adopted a non-binding resolution, 'To foster an enabling environment for the greater growth of the internet,' which stated that

'all governments should have an equal role and responsibility for international internet governance' and invited governments to 'elaborate on their respective positions on international internet-related technical, development and public policy issues within the mandate of ITU at various ITU forums. (ITU, 2012b)

The US declined to sign the treaty, and the head of the US delegation stated that the internet had 'given the world unimaginable economic and social benefits during these past 24 years-all without UN regulation. We candidly cannot support an ITU treaty that is inconsistent with a multi-stakeholder model of internet governance' (US Government, 2012). Of the 144 members of the ITU, 89 nations signed the treaty, while 55 either chose not to sign or abstained from voting, including the other three BRICS nations - India, Brazil and South Africa. While supporting the role of governments in internet regulation, these three argued for the representation of 
private interests and civil society groups. The Dubai meeting was labelled by The Economist as 'a digital version of the Cold War' (Economist, 2012).

Despite their differences over this, the BRICS nations have been increasingly challenging the US-created global internet regime and demanding greater internationalization of internet governance. China and Russia submitted a joint proposal on information security to the UN in 2011, while India, Brazil, and South Africa have been focusing on the information society since their 2003 Brasilia Declaration. Brazil's has been an important voice with regard to internet governance issues, for example, by promoting open source software (against strong US opposition). In March 2014, a month before NETmundial, an international conference organized by Brazil in Sao Paulo, the US government announced plans to relinquish its control over the Internet Assigned Numbers Authority (IANA), which is operated by ICANN, seen by many as a damage-control exercise post-Snowden revelations. NETmundial, described as a 'global multistakeholder meeting on the future of internet governance,' produced a non-binding 'NETmundial Multi-stakeholder Statement,' essentially reaffirming the multi-stakeholder model of internet governance. This demonstrated once again rifts among BRICS nations, who had been demanding that internet governance should reflect the fact that the internet was becoming more international: it stated that 'internet governance must respect, protect and promote cultural and linguistic diversity in all its forms' (NETmundial, 2014).

This internationalization was also emphasised by the Indian submission to the conference: 'The structures that manage and regulate the core internet resources need to be internationalized, and made representative and democratic' (Government of India, 2014a). The statement by the Indian representative at the Sao Paulo meeting talked of a 'trust deficit' in the system and criticised the multi-stakeholder model itself, demanding that the internet governance ecosystem [to] be sensitive to the cultures and national interests of all nations, not just of a select set of stakeholders'. Interestingly, the Indian position also questioned the presence of the non-governmental sector in governance negotiations: 'Given the important role that non-government stakeholders play,' the Indian representative said, 'there should also be a clear delineation of principles governing their participation - including their accountability, representativeness, transparency, and inclusiveness. Clearly, it 
makes it even more important that we define multistakeholderism' (Government of India, 2014b).

This is a concern shared by other BRICS nations. The non-governmental sector has grown in size and influence over the past two decades, the large majority of which are based in the West but operate across the world. They wield increasing clout within international forums, including internet governance deliberations and this has been seen by many as benefitting Western-based digital corporations. In countries with a democratic polity and an open economy, such as Brazil, India and South Africa, their presence is strong, while in Russia and China they remain marginal actors.

In the West, though, the so-called non-governmental sector is crucial in policy discourse, not least in relation to the future of the internet. One significant entrant is the Global Commission on Internet Governance, established in January 2014 by the US-based Centre for International Governance Innovation and UK's Chatham House, 'to help educate the wider public on the most effective ways to promote internet access, while simultaneously championing the principles of freedom of expression and the free flow of ideas over the internet'. This invoking of 'free flow' doctrine is reminiscent of the NWICO debates referred to at the beginning of the chapter.

As BRICS gain greater salience in global governance issues, will the internet infrastructure and architecture need reformulating? Will it lead to new cracks appearing in cyberspace? If China, Russia, Brazil and India, among other large nations, had their own 'national' internet, insulated from prying eyes of US corporate advertisers or intelligence agencies, what would happen to the World Wide Web? In the first paper released by the above mentioned Global Commission on Internet Governance, Joseph Nye writes: 'it is unlikely that there will be a single overarching regime for cyberspace any time soon. A good deal of fragmentation exists now and is likely to persist. The evolution of the present regime complex, which lies halfway between a single coherent legal structure and complete fragmentation of normative structures, is more likely' (Nye, 2014)

Eric Schmidt, Executive Chairman of Google and Jared Cohen, Director of Google Ideas, predict that the World Wide Web will 'fracture and fragment', leading to the 'Balkanisation' of the internet, with 'co-existing and sometimes overlapping but 
in important ways, separate' national systems. The internet in each of these 'internet Balkans', as they refer to them, 'would take on its national characteristics... the process would 'at first be barely perceptible to users, but it would fossilize over time and ultimately remake the internet' (Schmidt and Cohen, 2013: 85). Another form of 'Balkanization of the internet' has more serious economic implications if proposals in the US by some Internet Service Providers to create fast digital lanes for 'paid prioritization,' come about, whereby websites could charge for quality content delivered to subscribers at a faster speed. These digital lanes and by-lanes will also be aggressively utilized by governments to protect and promote their global interests.

\section{Soft power in the digital domain}

In his widely cited book Soft Power, Joseph Nye suggested one key source for a country's soft power is its foreign policies (when they are seen as legitimate and having moral authority)' (Nye 2004: 11). Despite Nye's focus being primarily on the US, the concept of soft power has also been adopted by BRICS nations, recognising the centrality of communication in contemporary international relations in a digitally connected and globalized environment with multiple media flows, involving both state and non-state actors and networks (Thussu, 2013).

The growing globalization of media content from BRICS countries - in terms of international television news emanating from China and Russia and deepening globalization of Bollywood and telenovelas from Brazil - offers new opportunities for soft power discourse. As the world becomes increasingly mobile, networked and digitised, will such cultural flows erode US hegemony? In his 2011 book The Future of Power, Nye explored the nature and shift in global power structures - from state to non-state actors and suggested that governments have to use 'smart power' ('neither hard nor soft. It is both'), making use of formal and informal networks and drawing on 'cyber power' (Nye, 2011).

The use of international broadcasting and personalized social media is adding another dimension to communicative power of governments and corporations, in a 'global networked society' (Castells, 2009). Soft power is increasingly communicated within a digital environment, as part of what is described as 'Public Diplomacy 2.0.' Castells has argued for a broader understanding of public diplomacy in such a connected space. He suggests that it: 
... seeks to build a public sphere in which diverse voices can be heard in spite of their various origins, distinct values, and often contradictory interests,' and recommends using it for developing 'a global public sphere around the global networks of communication, from which the public debate could inform the emergence of a new form of consensual global governance. (Castells, 2008: 91)

BRICS nations can learn from the US experience in this field. A US government report, National Framework for Strategic Communication, called for 'engagement' with foreign audiences to make public diplomacy more effective, using the possibilities offered by 'Web 2.0' to 'engage people directly,' adding that such connectivity 'allow[s] us to convey credible, consistent messages, develop effective plans and to better understand how our actions will be perceived' (US Government, 2009: 1). However, what makes the US a formidable media and cultural presence around the world is not government propaganda channels but a thriving and globalized private media. BRICS countries can provide a much needed corrective to a US-centric debate about soft power, especially by bringing culture into the global discourse. As Zahana argues, 'The role of culture as a force shaping public diplomacy represents a pressing research need, which at present is curiously unexplored' (Zaharna, 2010: 182).

In recent years, soft power initiatives have much progressed beyond the Western world. Both Russia and China have launched US-specific television operations, RT America and CCTV America, employing American staff, in an interesting example of news contra-flow. Russia, particularly, has experience of operating an extensive global propaganda machinery during the Soviet era, supporting anti-colonialism and anti-imperialism and promoting progressive causes around the Third World. During the NWICO debates, the issue of 'information imperialism' was widely discussed within anti-Western groups. In the digital age, the Russian media is increasingly using its online presence. The website of the Arabic version of Russia Today - Rusiya Al-Yaum - claims to draw on average 100,000 visitors every day, while RT's YouTube presence is also impressive.

China has used a combination of instruments, including public diplomacy, economic assistance, cultural exchanges and international broadcasting to promote its geopolitical and economic agenda. As Daniel Bell has noted, 'copying Western 
ways won't be sufficient for China to project its soft power' (2008: 19). A Chinese version of soft propaganda, largely circulated via CCTV News (with prominent operations in Kenya and the US), as well as international newspapers, such as the English-language China Daily, is resolutely delivered to an international audience by the Party-state in the form of an unabashedly official discourse promoting notions of the peaceful 'rise' of China on the global scene. Outside the official circuits, the growing global presence of Chinese students, business executives and tourists contribute to a people-to-people conversation, arguably more effectively than statesponsored, external communication projects, which include broadcasting and online presence, as well as the proliferation of Confucius Institutes across the globe (Wang, 2010; Lai and Lu, 2012).

Indian soft power in the digital domain remains limited, although the Indian government has belatedly woken up to the need to expand its external broadcasting. A high-powered committee in 2014 recommended that Prasar Bharati, India's public broadcaster, should have a 'global outreach'. Its vision is ambitious:

Create a world-class broadcasting service benchmarked with the best in the world using next-generation opportunities, technologies, business models and strategies. The platform should be designed for new media first and then extended to conventional TV. Outline an effective content strategy for Prasar Bharati's global platforms (TV and Radio) focused on projecting the national view rather than the narrow official viewpoint. (Prasar Bharati, 2014: 15).

Such attitudes will certainly help increase the Indian presence in the international sphere, especially with the growth of English-language media in India and the globalization of Indian media industries. The expert committee has proposed the establishment of Prasar Bharati Connect, which would be tasked with managing the state broadcaster, Doordarshan's websites 'to make them more appealing, interactive, and engaging, and also integrate them with the existing social media channels' (Prasar Bharati, 2014: 33). In August 2014, Doordarshan signed an agreement with Deutsche Welle to distribute Indian public television to the European market. According to Prasar Bharati CEO, Jawahar Sircar, this aims to 'provide an important platform to position DD's content globally and projecting India's viewpoint to a global audience' (Quoted in Business Line, 2014). 
News 18 India, the country's leading 24/7 news network, also launched a channel in the US, its mission described by its CEO as 'at a time when the world is watching India, News18 India will serve as the world's window into India.' (Television Post, 2014). News 18 India, along with many other Indian news channels, are available to South Asian diaspora markets, including in Britain, Singapore, and the Arabian Gulf states.

For private news networks, the need for global expansion is limited, since, in market terms, news has a relatively small audience and therefore meagre advertising revenue. For the other two major BRICS countries - China and Russia these commercial considerations are not particularly significant as their news networks are generously funded by their respective governments. For India, Brazil and South Africa, entertainment is what defines their global media presence and, as digital connectivity grows in these countries, media products such as Bollywood and Bollywoodized content from India, telenovelas from Brazil and television entertainment from South Africa, are likely to increase circulation in global digital space. In 2014, there was more material from Bollywood than Hollywood on You Tube (Thussu, 2013). As social media proliferate further and become more multilingual, user-generated content will be produced by many more consumers in much higher volumes and velocity in an open and leaky information system, making governments attempts to control information increasingly difficult, even if the internet is 'nationalized'. In such a rapidly changing communication ecology, the mandarins of Public Diplomacy 2.0 have to adapt to this reality to understand how the politics of cyber-space influences international relations (Choucri, 2012).

\section{BRICS building a NWICO 2.0?}

Will the rise of the BRICS create a New World Information and Communication Order for the digital age? The issues surrounding global information imbalances was one of the central planks of the NWICO debates, and much of the debate - led by the Non-Aligned countries - was framed in the context of news agencies. In today's transformed media environment, new issues have emerged, as noted above, but old concerns about asymmetries in media power persist and have even been consolidated, though geo-political and economic equations are changing with BRICS nations - particularly China - emerging as a significant global voice. A World Bank 
report predicts that 'China will account for 30 per cent of global investment by 2030 , while Brazil, India, and Russia, together, will account for more than 13 per cent of global investment in 2030, more than the United States' (World Bank, 2013: 5).

The state remains an extremely important actor among BRICS nations particularly in China and Russia - in some way an antidote to the globalization theorists' notions of the 'withering away' of the state under the pressures of market forces. Braman has argued that states retain huge power, including informational power 'that shapes human behaviour by manipulating the informational bases of instrumental, structural, and symbolic power' (Braman, 2006: 25). In a globalized knowledge economy, the state's role is likely to continue to define international relations. The Thomson Reuters Derwent World Patents Index reported that in 2011 China overtook the US to become the world's top filing country for invention patents, with 526,412 applications compared to the US count of 503,582. More Chinese residents were granted patents than Americans (112,347 compared to 108,626). Brazil and India also showed impressive progress in patents in pharmaceuticals, while Russia was notable in medical technology. Apart from electrical machinery, apparatus and energy, Chinese patents were in such areas as digital communication and computer technology (Adams et al, 2013).

A possible synergy of cyberspace with efforts toward sustainable development is an arena where BRICS nations could contribute significantly. BRICS countries have sophisticated space and satellite programmes: Russian expertise in this field is well-established, being the first country to send a human to space; China has demonstrated exceptional growth in this sector, while the Indian Space Research Organization, which has built and launched a range of satellites at affordable rates, can provide communication infrastructure to counter, the traditional domination of this field by the US and the European Union. Brazil's plan to build an undersea cable - to link South America to Europe - is another example of this shift though the initial idea of building a BRICS undersea cable was dropped (see Zhao in this volume).

The aid budget of BRICS nations is also growing, with China emerging as the largest donor from the developing world, followed by India: Indian foreign assistance has tripled in the last decade. Russia has particularly significant role in terms of energy support and in the field of defence industries (Graham, 2013), while Brazil 
has significantly increased its foreign aid to many countries in Africa. BRICS champions a qualitatively different development discourse and these nations can benefit from greater policy synergies and intellectual exchanges to share experience on such issues as Intellectual Property Rights, climate change, health and education (Amar, 2012; Hurrell and Sengupta, 2012). Already, these conversations have begun: a recent Working Paper from the Russian International Affairs Council states: 'The prospects of building further links between Russian research (and its resources) and India's engineering skills (which can be witnessed already in the military realm) supplemented by low-cost Chinese labour with sufficient quality level look extremely promising' (RIAC, 2013: 14).

India could learn from China's exceptionally successful programme of drastically reducing if not eliminating poverty and Brazil's clean-fuel energy programmes (Cepaluni and Vigevani, 2012; Trinkunas, 2014). The 'Civil Law Marco Internet'- dubbed the internet Bill of Rights - passed by Brazil at the launch of the NETmundial conference referred to earlier, stipulates that companies such as Google and Facebook will be subject to Brazil's laws and courts in cases involving information on Brazilians, even if the data is stored on servers abroad. Such laws help protect citizens from any violations of their digital rights and should encourage other nations to follow suit. As DeNardis has stressed, it is a crucial imperative for the public to actively engage in issues surrounding internet governance as they will ultimately determine internet freedom (DeNardis, 2014).

BRICS nations could provide a new impetus to digital education too. The creation of a BRICS Academic Forum that meets annually could consolidate this agenda. Given its strong information technology sector - it accounted for 58 per cent of the global outsourcing industry in 2012 - India could play a useful role within the BRICS constellation. Such programmes as Aadhaar (Sanskrit for foundation) - the world's biggest IT project aimed to provide a unique identification number for every Indian citizen to ensure that they receive entitlements under various welfare schemes - could be replicated in similar situations in other developing countries. India was the first country to deploy satellite television for developmental communication through its 1970s SITE (Satellite Instructional Television Experiment) programme. Its Open Universities could provide online education in English to students across the globe: a government initiative - the National Programme on 
Technology Enhanced Learning-to provide online lectures through YouTube, received 62 million views (Government of India, 2012: 23). From tele-medicine, to tele-education and from mobile banking to e-governance, the opportunities that the digital connectivity offers are tremendous.

As one of the founding members of the Non-Aligned Movement, India was a leading voice during the NWICO debates and a key component of the Non-aligned News Agencies Pool, an attempt to encourage South-South news exchange to counter Western information hegemony. In the age of BRICS, coinciding with cracks within the neo-liberal model of US-led capitalism, there is now talk of Non-Alignment 2.0 (Khilnani et al, 2012). Could such a media discourse contribute to finding approaches which transcend the binaries of Orientalism and Occidentalism to create a new paradigm within which to understand a more inclusive version of globalization, beyond Western formulations? Castells has argued that 'power is primarily exercised by the construction of meaning in the human mind through processes of communication enacted in global/local multimedia networks of mass communication, including mass self-communication' (Castells, 2009: 416).

BRICS could be an important voice in articulating Southern viewpoints and perspectives in global forums like UNESCO, ITU and WIPO on such diverse and contested issues as sustainable development, multiculturalism, intellectual property rights in the digital environment, safeguarding of media plurality and indigenous media. However, as elsewhere, most of media in BRICS countries is entrenched in a culture thriving on entertainment and infotainment-driven programming, rooted in a commercial system, which has even affected state-controlled media as in China. In the age of what has been termed 'spreadable media', content is increasingly produced, distributed and consumed by a myriad of networked audiences, who communicate through formal and informal nodes (Jenkins, Ford and Green, 2013). By overwhelming public discourse with infotainment, egalitarian aspects are marginalized in the news media, at a time when at least four out the five BRICS nations are home to nearly 600 million people living in poverty and enduring deeply unequal social and economic relations, which, despite economic growth are, in some cases, being exacerbated, a trend seen globally, and eloquently expounded by French economist Thomas Piketty (Piketty, 2013). 
The issues that confront many BRICS nations - about good governance, sustainable development, poverty - have striking resonances in many other countries in the global South. Despite BRICS nations gradual integration with the US-led neo-liberal economic system, there is a strong tradition of intellectual and political engagement among BRICS populations, whether socialistic approaches in Russia and China, community activism in Brazil or anti-colonial sentiments in India and South Africa. As BRICS media globalize, will this critical mass contribute to strengthening the voice of the South on the global scene or will they act as surrogates to the US-dominated entertainment-driven media?

The US and Europe are to initiate a 'Transatlantic Trade and Investment Partnership', to further integrate trade and investment structures and policies to counter such groupings as BRICS, an indication of the changing global power equations (Gilboy and Heginbotham, 2012; Goldstein, 2013; Sidhu, Mehta and Jones, 2013; Narlikar, 2013; Johnston, 2013; Acharya, 2014). A 2014 Pew Survey showed that, in 2008, in France, Germany, Poland, Spain and Britain, 44 per cent considered the US to be the world's top economy, while just 29 per cent said it was China. By 2012, the percentage naming the US had declined to 28 per cent, while the share saying China had nearly doubled to 57 per cent' (Pew Research Center, 2014: 12).

As Chin and Thakur suggest, 'The multilateral order cannot hold if the power and influence embedded in international institutions is significantly misaligned with the real distribution of power' (Chin and Thakur, 2010:119). However, the BRICS nations remain divided on crucial policy issues, as noted above in relation to internet governance. As yet, it has been suggested, there is not 'a shared vision of what a radically different world order might look like. Rather, the agenda seems to focus primarily on the redistribution of power within the existing order' (Breslin, 2013: 629, italics in original).

ICANN notes that the internet has 'allowed for the sharing of knowledge, creativity and commerce in a global commons,' but this commons has been transformed in the years since ICANN was formed in 1998, when merely four per cent of the world's population was online, with half of those users in the US. By 2020, it estimates that 63 per cent of the world's population will be online (five billion users), many of whom will not use Latin keyboards.' (Cerf et al, 2014). This multi- 
lingual internet will contribute to its long overdue internationalization and encourage its study to go beyond Anglophone approaches (Goggin and McLelland, 2009). However, what Schmidt and Cohen have called 'a digital caste system' will probably remain (Schmidt and Cohen, 2013: 254), as the US domination of the internet is not likely to disappear in the foreseeable future, although it will be a different internet: China and India will account for nearly half of new mobile internet users in the next five years, but this 'will come with significant cultural, commercial and political challenges' (PwC, 2014).

According to India's twelfth Five Year Plan (2012-2017), the country requires $\$ 1$ trillion to improve its backward infrastructure. China is in possession of more than $\$ 3$ trillion in reserves and keen to invest in stable markets. The pro-business new government in New Delhi led by Narendra Modi is trying to encourage Chinese investment. This 'Chindian' exchange is likely to strengthen the BRICS bloc, especially now that a BRICS bank has been set up and may lead to a new kind of economic globalization, almost parallel to the Western-dominated Bretton Woods system. As a World Bank report notes: 'in a multipolar world, South-South monetary policy coordination will become more critical in promoting stable financial and macroeconomic conditions in developing countries' (World Bank, 2013: 144). The US is still recovering from what Nobel laureate Joseph Stiglitz has called a 'three trillion dollar war' - the 'war on terror'(Stinglitz and Bilmiss, 2008), while the Euro continues to be weak. It may be a mere coincidence that the currencies of the BRICS countries all start with the letter R: Real, Rouble, Rupee, Renminbi, Rand. There is little doubt, however, that the BRICS should contribute to a more pluralistic and multi-perspectival media globe and that a BRICS internet would be a crucial node within this networked world. Will a NWICO 2.0, fuelled by rising powers like BRICS, reconfigure the global communication discourse?

\section{References}

Acharya, Amitav (2014) The End of American World Order. Cambridge: Polity 
Adams, Jonathan; Pendlebury, David and Stembridge, Bob (2013) Building BRICKs: Exploring the Global Research and Innovation Impact of Brazil, Russia, India, China and South Korea. London: Thomson Reuters. February.

Amar, Paul (2012) Global South to the Rescue: Emerging Humanitarian

Superpowers and Globalizing Rescue Industries, Globalizations 9(1): 1-13.

Bell, Daniel (2008) China’s New Confucianism. Princeton: Princeton University Press.

Bhuiyan, Abu (2014) Internet Governance and the Global South: Demand for a New Framework. London: Palgrave Macmillan.

Braman, Sandra (2006) Change of State: Information, Policy, and Power. Cambridge (Mass.): MIT Press.

Breslin, Shaun (2013) China and the Global Order: Signalling Threat or Friendship? International Affairs 89 (3): 615-634.

Business Line (2014) Doordarshan signs pact with German channel, Business Line, August 5.

Castells, Manuel (2008) The New Public Sphere: Global Civil Society, Communication Networks and Global Governance, The ANNALS of the American Academy of Political and Social Science; 616: 78-93.

Castells, Manuel (2009) Communication Power. Oxford: Oxford University Press.

Cepaluni, Gabriel and Vigevani, Tullo (2012) Brazilian Foreign Policy in Changing Times: The Quest for Autonomy from Sarney to Lula. Lanham, MD: Lexington Books. 
Cerf, Vinton et al (2014) Strategy Report: ICANN's Role in the internet Governance Ecosystem. ICANN. Available at http://goo.gl/9WrOCD.

Chin, Gregory and Thakur, Ramesh (2010) Will China Change the Rules of Global Order?, Washington Quarterly 33 (4): 119-138.

Choucri, Nazli (2012) Cyber-Politics in International Relations. London: MIT Press.

DeNardis, Laura (2014) The Global War for Internet Governance. New Haven: Yale University Press.

Economist (2012) Internet Regulation: A Digital Cold War? The Economist, December 14.

Economist (2014) Defending the Digital Frontier: A Special Report on Cyber-security, The Economist, 12 July.

Ebert, Hannes and Maurer, Tim (2013) Contested Cyberspace and Rising Powers, Third World Quarterly, 34(6):1054-1074.

Ericsson Mobility Report (2014) Ericsson Mobility Report: On the Pulse of the Networked Society. Stockholm: Ericsson, June.

FICCI-KPMG (2014) The Stage is Set - FICCI-KPMG Indian Media and Entertainment Industry Report 2014. Mumbai: KPMG in association with Federation of Indian Chambers of Commerce and Industry.

Fuchs, Christian; Boersma, Kees; Albrechtslund, Anders and Sandoval, Marisol (eds.) (2011) Internet and Surveillance: The Challenges of Web 2.0 and Social Media. New York: Routledge.

Gilboy, George and Heginbotham, Eric (2012) Chinese and Indian Strategic Behavior: Growing Power and Alarm. New York: Cambridge University Press. 
Gnanasambandam, Chandra; Madgavkar, Anu; Kaka, Noshir; Manyika, James;

Chui, Michael; Bughin, Jacques and Gomes, Malcolm (2012) Online and Upcoming: The Internet's Impact on India. McKinsey \& Company, December.

Graham, Loren (2013) Lonely Ideas: Can Russia Compete? New Haven: Yale University Press.

Goggin, Gerard and McLelland, Mark (eds.) (2009) Internationalizing Internet Studies: Beyond Anglophone Paradigms. London: Routledge.

Goldstein, Andrea (2013) The Political Economy of Global Business: The Case of the BRICs. Global Policy 4(2):162-172.

Government of China (2010) The Internet in China, chapter 6, Beijing: Information Office of the State Council of the People's Republic of China, June 8, http://www.gov.cn/english/2010-06/08/content_1622956.htm

Government of India (2012) Ministry of Human Resource Development, Education Annual Report 2011-2012. New Delhi: Ministry of Human Resource Development.

Government of India (2014a) Government of India's Initial Submission to Global Multi-stakeholder Meeting on the Future of Internet Governance; Sao Paulo, Brazil on April 23-24. Available at:

http://mea.gov.in/Images/pdf/official submission to the conference.pdf

Government of India (2014b) Statement by Vinay Kwatra, Indian representative at the Global Multi-stakeholder Meeting on the Future of Internet Governance in Sao Paulo, Available at: http://mea.gov.in/Speeches-

Statements.htm?dt//23246/Statement+by+Mr+Vinay+Kwatra+Indian+representativ

Hurrell, Andrew and Sengupta, Sandeep (2012) Emerging Powers, North-South Relations and Global Climate Politics, International Affairs 88(3): 463-484. 
ITU (2012a) Document 47-E, Proposal by Algeria, Saudi Arabia, Bahrain, China, UAE, Russia, Iraq and Sudan, World Conference on International

Telecommunications December 11, International Telecommunications Union, Available at http://files.wcitleaks.org/public/S12-WCIT12-C-0047!!MSW-E.pdf.

ITU (2012b) Final Acts of the World Conference on International Telecommunications, Dubai, International Telecommunications Union, December. Available at http://www.itu.int/en/wcit-12/Documents/final-acts-wcit-12.pdf.

Jenkins, Henry; Ford, Sam and Green, Joshua (2013) Spreadable Media. New York: New York University Press.

Johnston, Alastair (2013) How New and Assertive is China's New Assertiveness? International Security 37(4): 7-48.

Khilnani, Sunil; Kumar, Rajiv; Mehta, Pratap Bhanu; Menon, Prakash; Nilekani, Nandan; Raghavan, Srinath; Saran, Shyam and Varadarajan, Siddharth (2012) Nonalignment 2.0: A Foreign and Strategic Policy for India in the Twenty First Century, New Delhi: National Defence College and Centre for Policy Research, 30 January.

Kruger, Lennard (2014) Internet Governance and the Domain Name System: Issues for Congress. Washington: Congressional Research Service.

Lai, Hongyi and Lu, Yiyi (eds.) (2012) China's Soft Power and International Relations. London: Routledge.

Lewis, James and Baker, Stewart (2013) The Economic Impact of Cybercrime and Cyberespionage. CSIS report. http://csis.org/files/publication/60396rpt cybercrimecost 0713 ph4 0.pdf. 
Masmoudi, Mustafa (1979) The New World Information Order. Journal of Communication, 29(2): 172-85.

Mosco, Vincent (2014) To the Cloud: Big Data in a Turbulent World. New York: Paradigm.

Mueller, Milton (2010) Networks and States: The Global Politics of Internet Governance. London: MIT Press.

Narlikar, Anita (2013) India Rising: Responsible to Whom? International Affairs, 89(3): 595-614.

NETmundial Multistakeholder Statement, April 24, 2014, available at http://goo.gl/f3ziWZ

Newman, Nic and Levy, David (eds.) (2014) Reuters Institute Digital News Report 2014: Tracking the Future of News. Oxford: Reuters Institute for the Study of Journalism.

$\mathrm{Ng}$, Jason (2013) Blocked on Weibo: What Gets Suppressed on China's Version of Twitter (and Why). New York: The New Press.

Nordenstreng, Kaarle and Padovani, Claudia (2005) From NWICO to WSIS: Another World Information and Communication Order. Global Media and Communication 1(3):264-272.

Nordenstreng, Kaarle (2012) The New World Information and Communication Order: An Idea That Refuses to Die, pp. 477-499, in Media History and the Foundations of Media Studies, Volume 1, The International Encyclopedia of Media Studies edited by John Nerone. Oxford: Wiley-Blackwell.

Nye, Joseph (2004) Soft Power: The Means to Success in World Politics. New York: Public Affairs. 
Nye, Joseph (2011) The Future of Power. New York: Public Affairs.

Nye, Joseph (2014) The Regime Complex for Managing Global Cyber Activities. Paper Series: No. 1, May, London: Centre for International Governance Innovation and the Royal Institute for International Affairs

Pew Research Center (2014) Global Opposition to U.S. Surveillance and Drones but Limited Harm to America's Image, July. Washington: Pew Research Center.

Pickard, Victor (2007) Neo-liberal Visions and Revisions in Global Communication Policy from NWICO to WSIS. Journal of Communication Inquiry, 31(2):118-139.

Piketty, Thomas (2013) Capital in the Twenty-First Century. Cambridge (Mass): Harvard University Press.

Prasar Bharati (2014) Report of the Expert Committee on Prasar Bharati. Vol. I and II, New Delhi: Government of India: Prasar Bharati.

PwC (2014) PwC Annual Global Entertainment and Media Outlook, London: PriceWaterhouseCooper.

RIAC (2013) Postulates on Russia-India Relations. Working Paper No. 3. Moscow: Russian International Affairs Council.

Rid, Thomas (2013) Cyber War will not take Place. New York: Oxford University Press.

Schmidt, Eric and Cohen, Jared (2013) The New Digital Age: Reshaping the Future of People, Nations and Business. London: John Murray.

Schneier, Bruce (2013) The Battle for Power on the Internet. The Atlantic, October 24. 
Sidhu, Waheguru Pal Singh; Mehta, Pratap Bhanu and Jones, Bruce (2013) A Hesitant Rule Shaper? pp. 3-22 in Shaping the Emerging World: India and the Multilateral Order, edited by Waheguru Pal Singh Sidhu, Pratap Bhanu Mehta, and Bruce Jones. Washington: Brookings Institution Press.

Stiglitz, Joseph and Bilmiss, Linda (2008) The Three Trillion Dollar War: The True Cost of the Iraq Conflict. New York: W.W. Norton.

Television Post (2014) News18 India launches in the US. Television Post, 1 August, Available at: http://www.televisionpost.com/television/news18-india-launches-in-theus/| TelevisionPost.com

Thoppil, Dhanya Ann (2014) India's Flipkart Raises \$1Billion in Fresh Funding. Wall Street Journal, July 29.

Thussu, Daya Kishan (2013) Communicating India's Soft Power: Buddha to Bollywood. New York: Palgrave/Macmillan.

Thussu, Daya Kishan (2015) International Communication: Continuity and Change, Third Edition, New York: Bloomsbury Academic.

Trinkunas, Harold (2014) Brazil's Rise: Seeking Influence on Global Governance. Washington: Brookings Institute.

UNESCO (2013) Emerging Markets and the Digitalization of the Film Industry. An Analysis of the 2012 UIS International Survey of Feature Film Statistics. Paris: Institute for Statistics, United Nations Educational, Scientific and Cultural Organization, August.

UNESCO (2014) World Trends in Freedom of Expression and Media Development. Paris: United Nations Educational, Scientific and Cultural Organization. 
U S Government (2009) National Framework for Strategic Communication. Washington: White House.

US Government (2012) Statement delivered by Ambassador Terry Kramer from the floor of the WCIT, December 13, 2012. U.S. Department of State, Press Release, 'U.S. Intervention at the World Conference on International Telecommunications,' December 13, 2012. Available at:

http://www.state.gov/r/pa/prs/ps/2012/12/202037.htm

US Government (2014) Big Data: Seizing Opportunities, Preserving Values, Washington: The White House, May.

WAN-IFRA (2014) Trends in Newsrooms 2014. Paris: The World Association of Newspapers and News Publishers.

Wang, Jian (ed.) (2010) Soft Power in China: Public Diplomacy through Communication. New York: Palgrave Macmillan.

Wells, Clare (1987) The UN, UNESCO and the Politics of Knowledge. London: Macmillan.

WSIS (2005) Tunis Agenda for the Information Society, November 18, 2005, WSIS05/TUNIS/DOC6(Rev.1)-E, p. 6, available at http://www.itu.int/wsis/docs2/tunis/off/6rev1.pdf.

World Bank (2013) Global Development Horizons 2011-Multipolarity: The New Global Economy. Washington, DC: World Bank Publications.

Yang, Guobin (2009) The Power of the Internet in China: Citizen Activism Online. New York: Columbia University Press.

Zaharna, Rhonda (2010) Battles to Bridges US Strategic Communication and Public Diplomacy After 9/11. New York: Palgrave Macmillan. 
